W

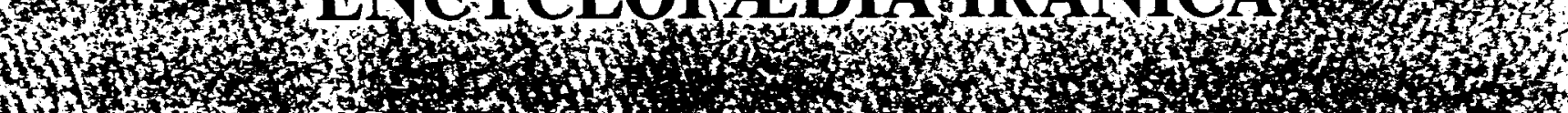
N. 1.

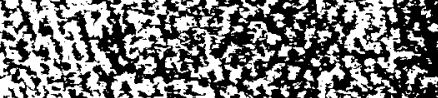

x (1) 10.

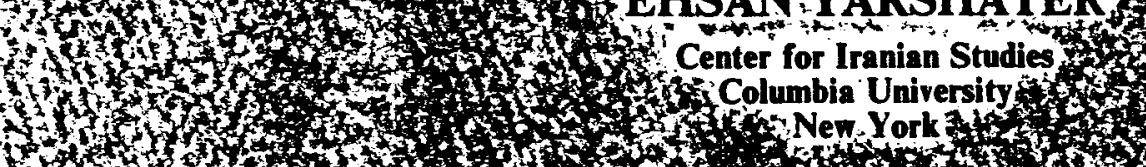

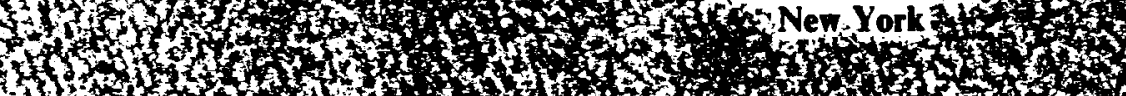

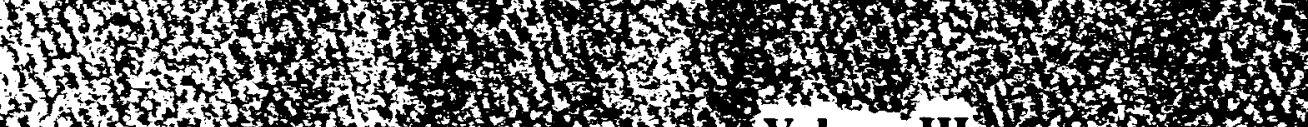
17. W.1, 17.

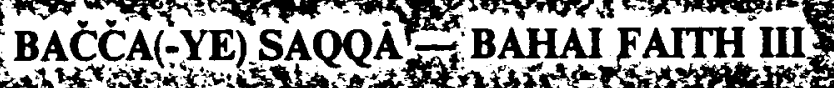
371 60

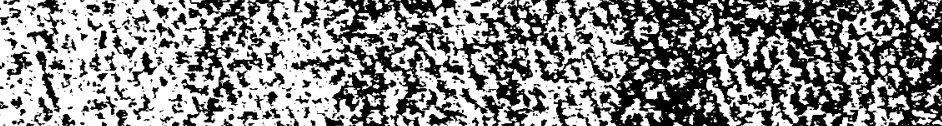
14: \begin{tabular}{|l}
\hline \\
\hline
\end{tabular}

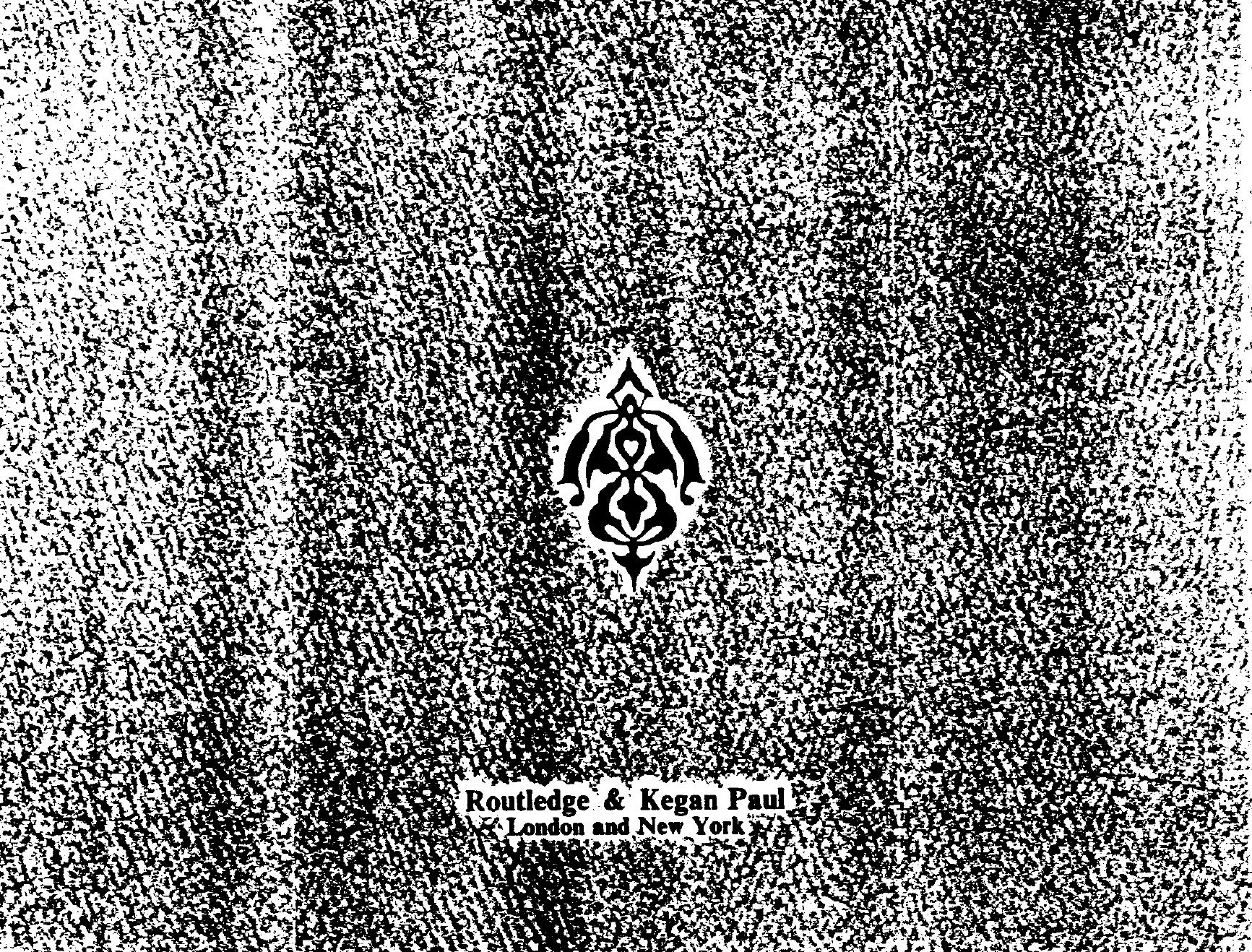

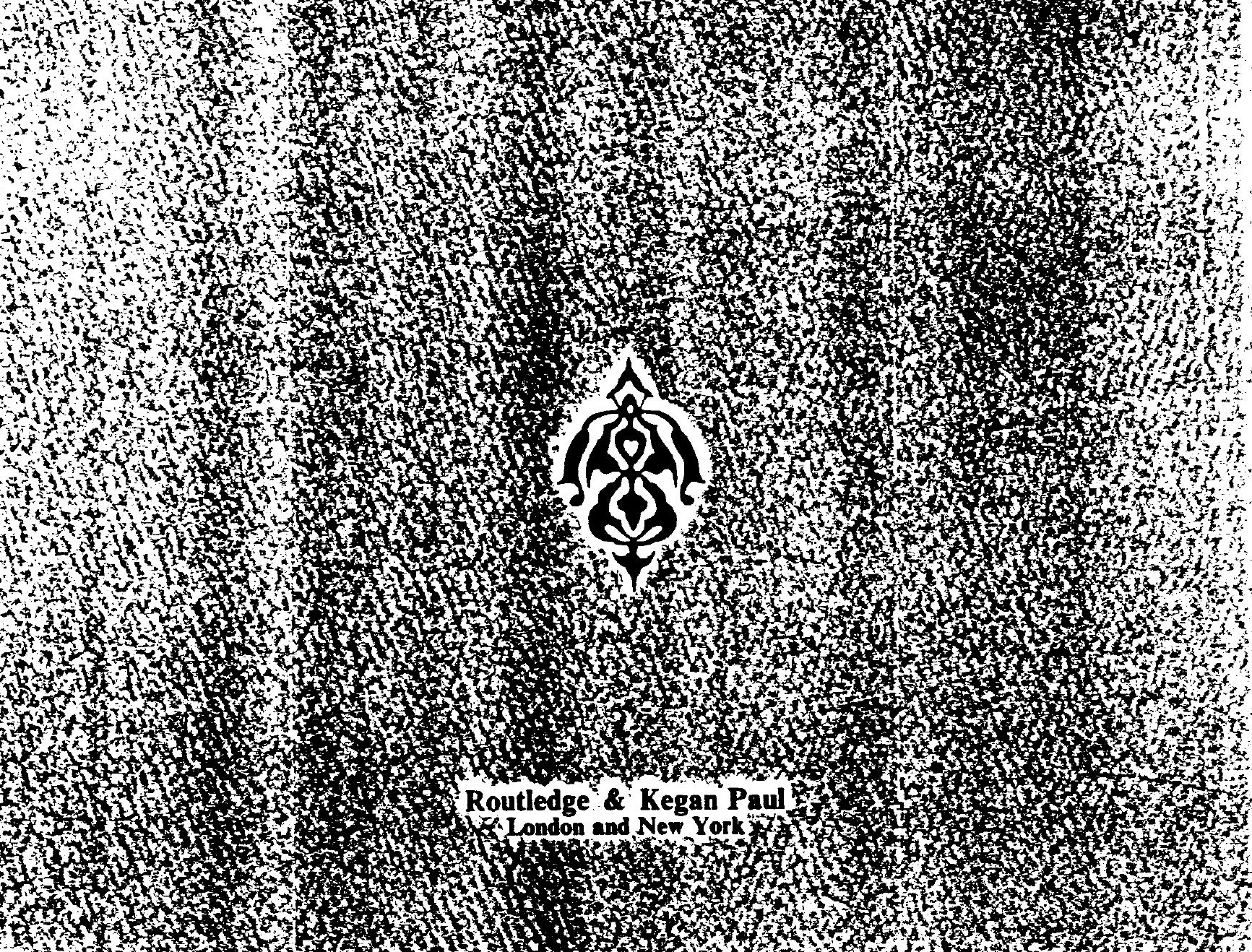

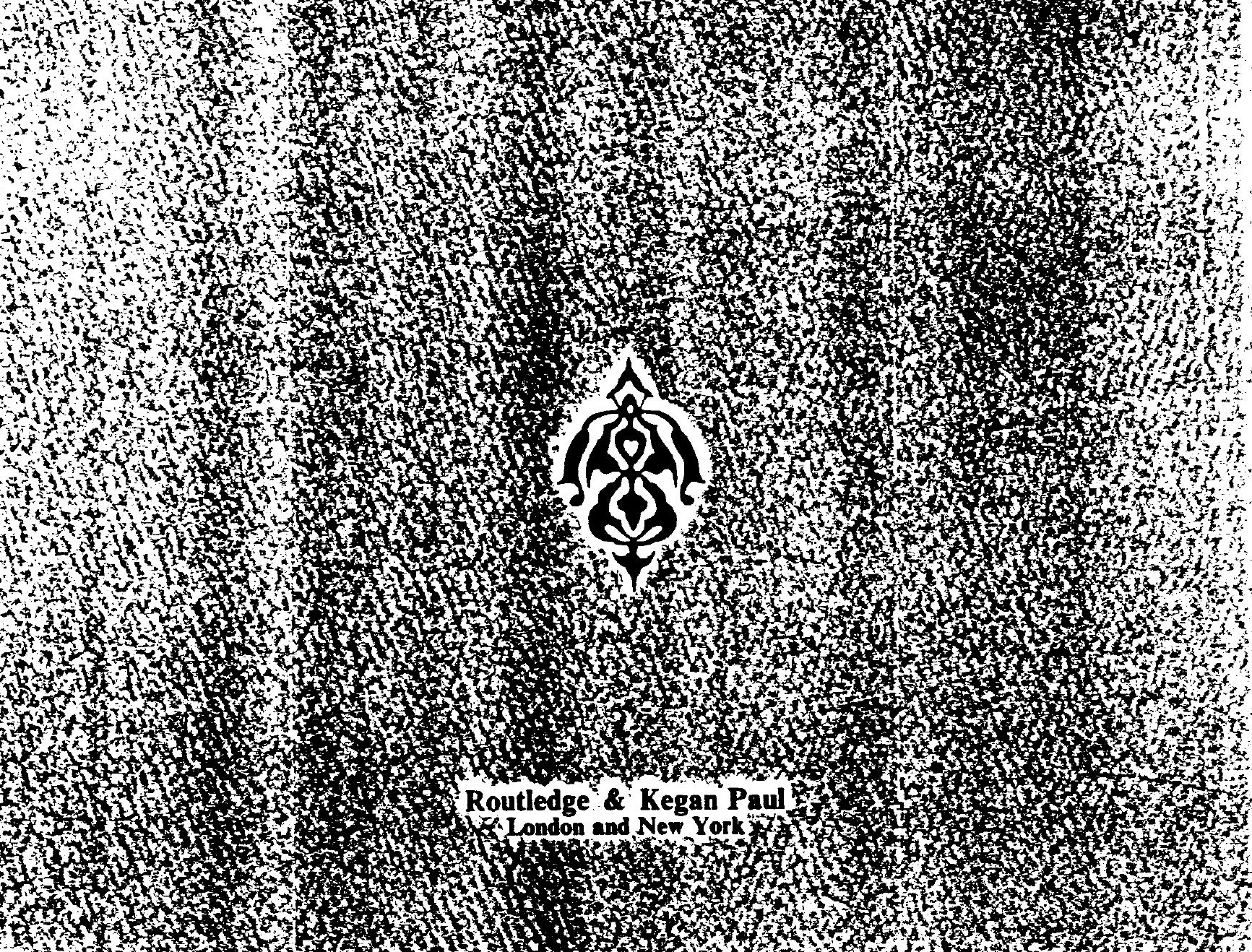

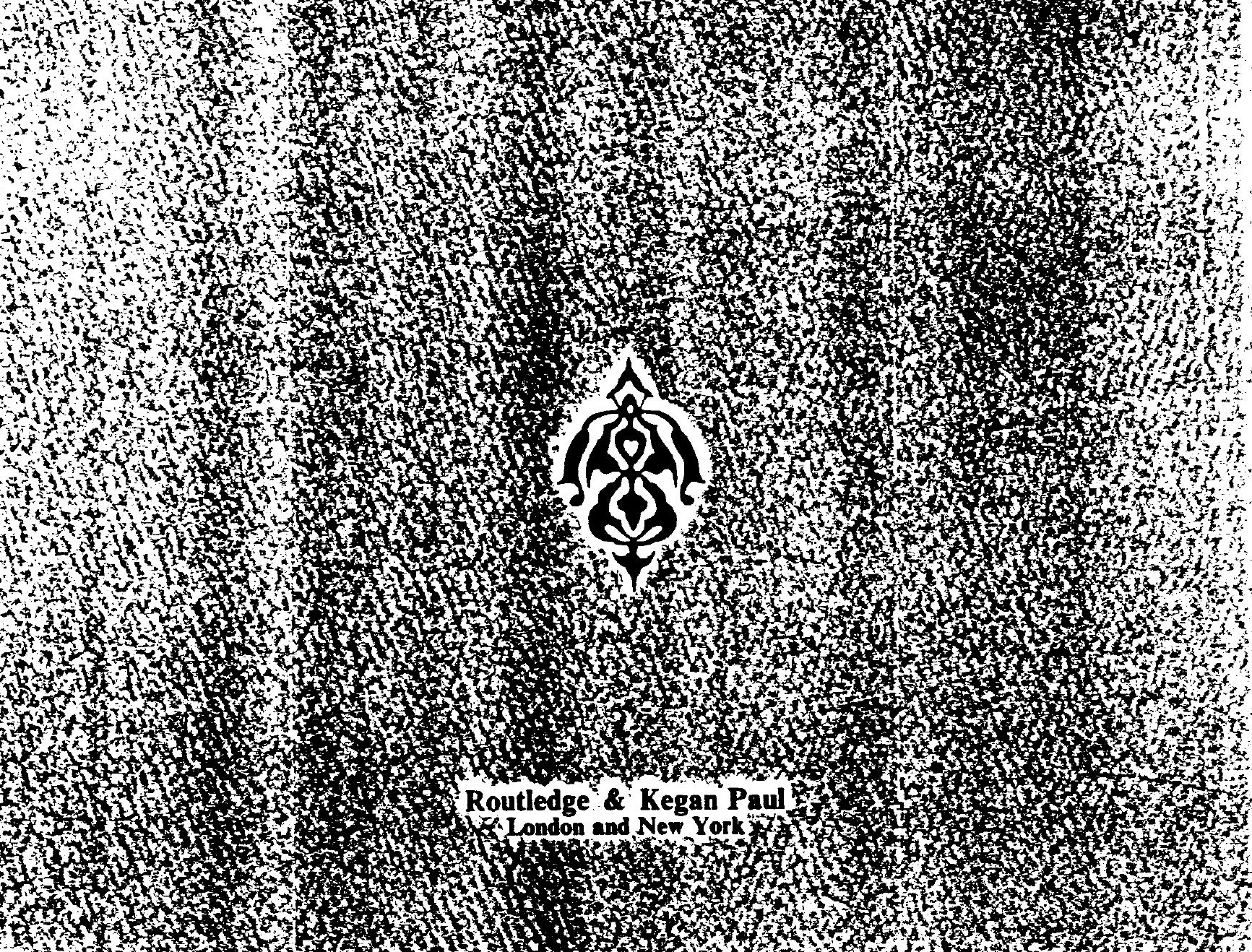

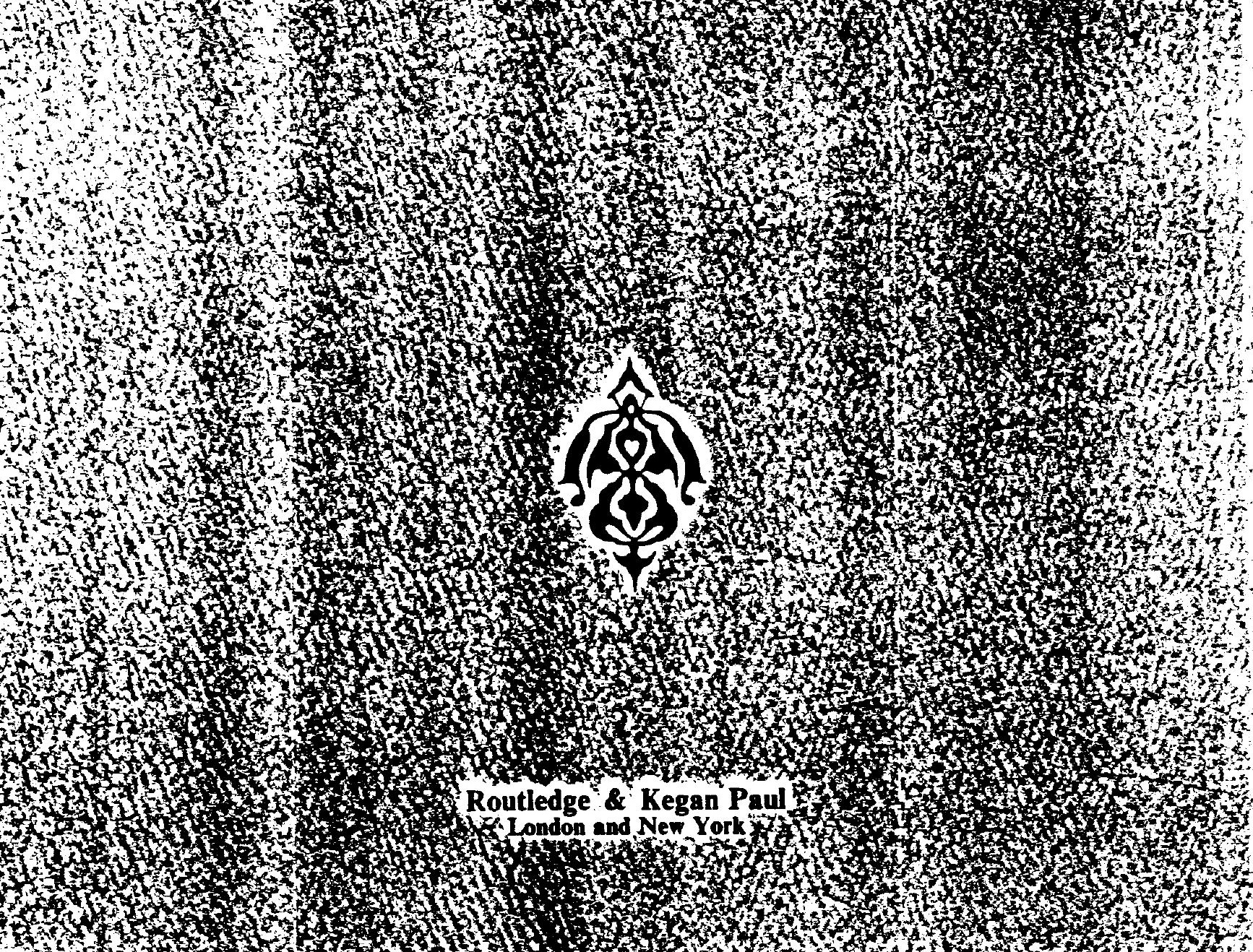

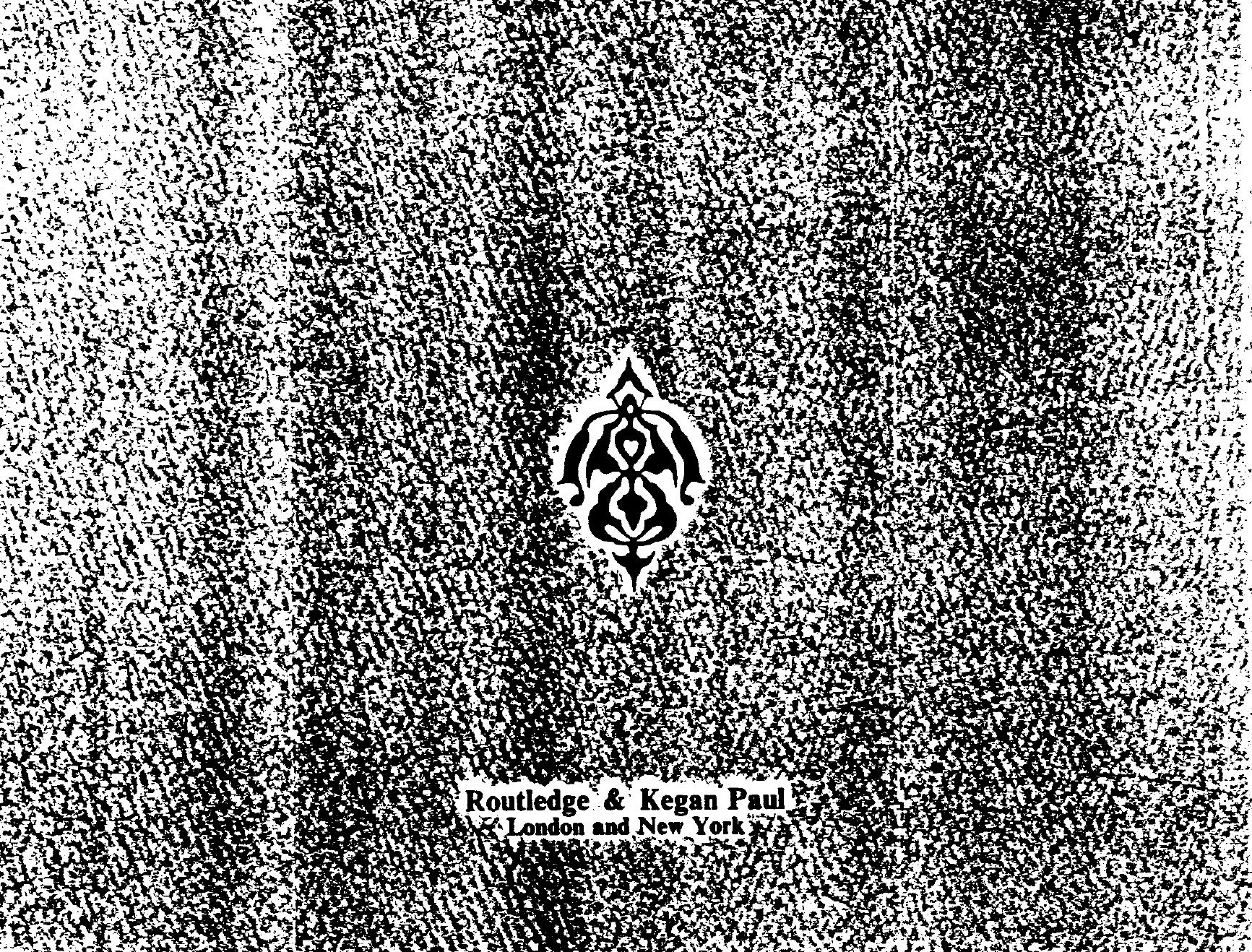

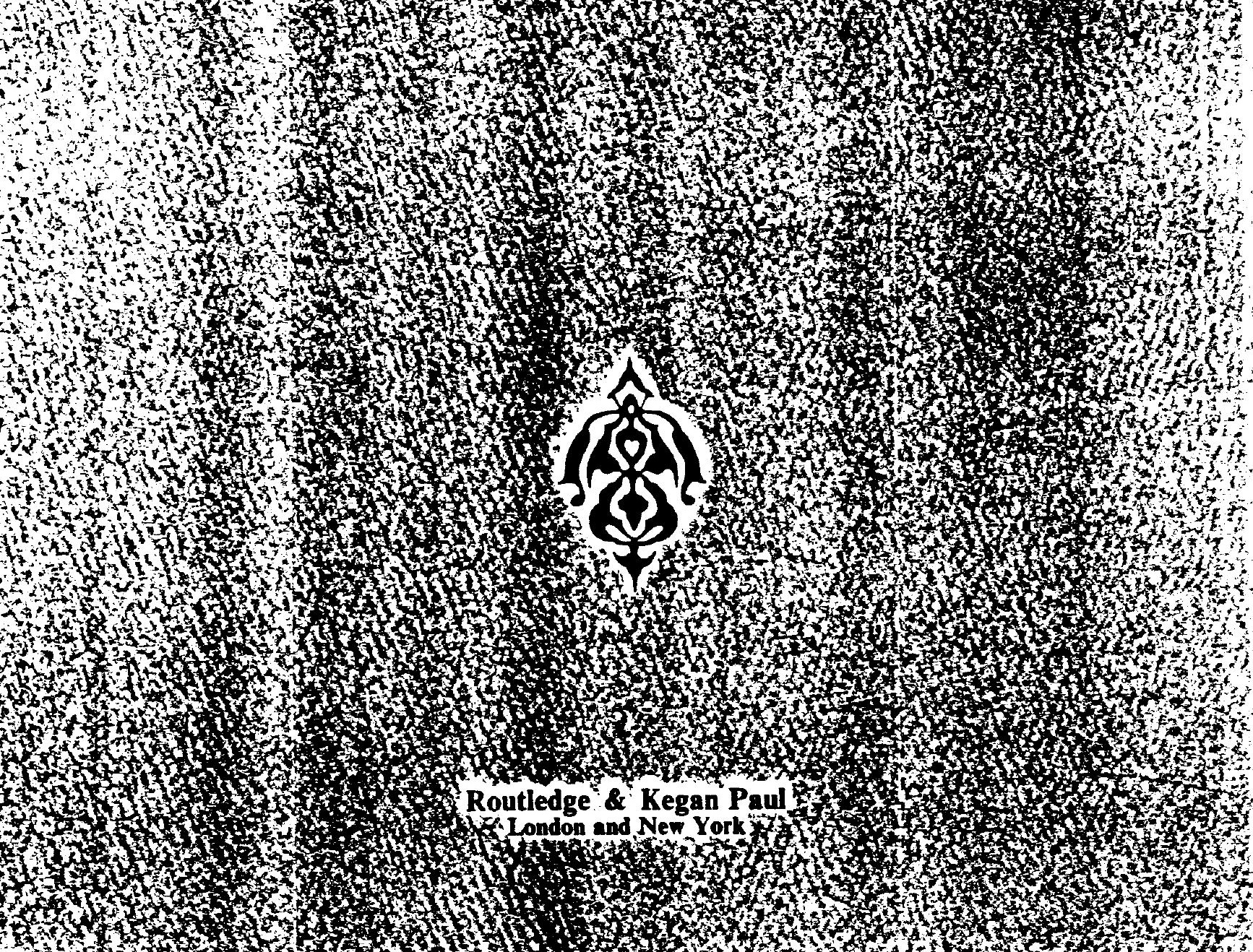

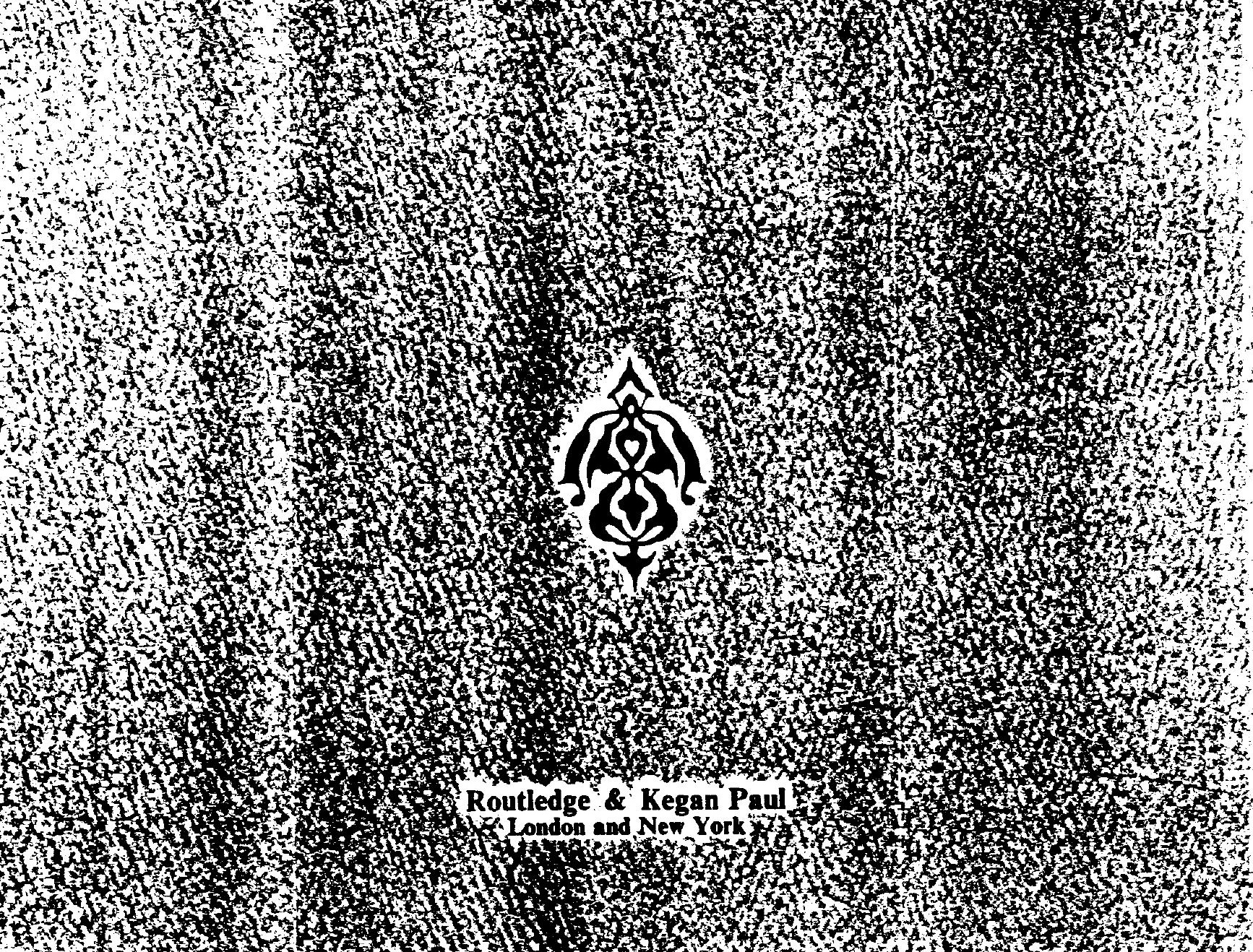

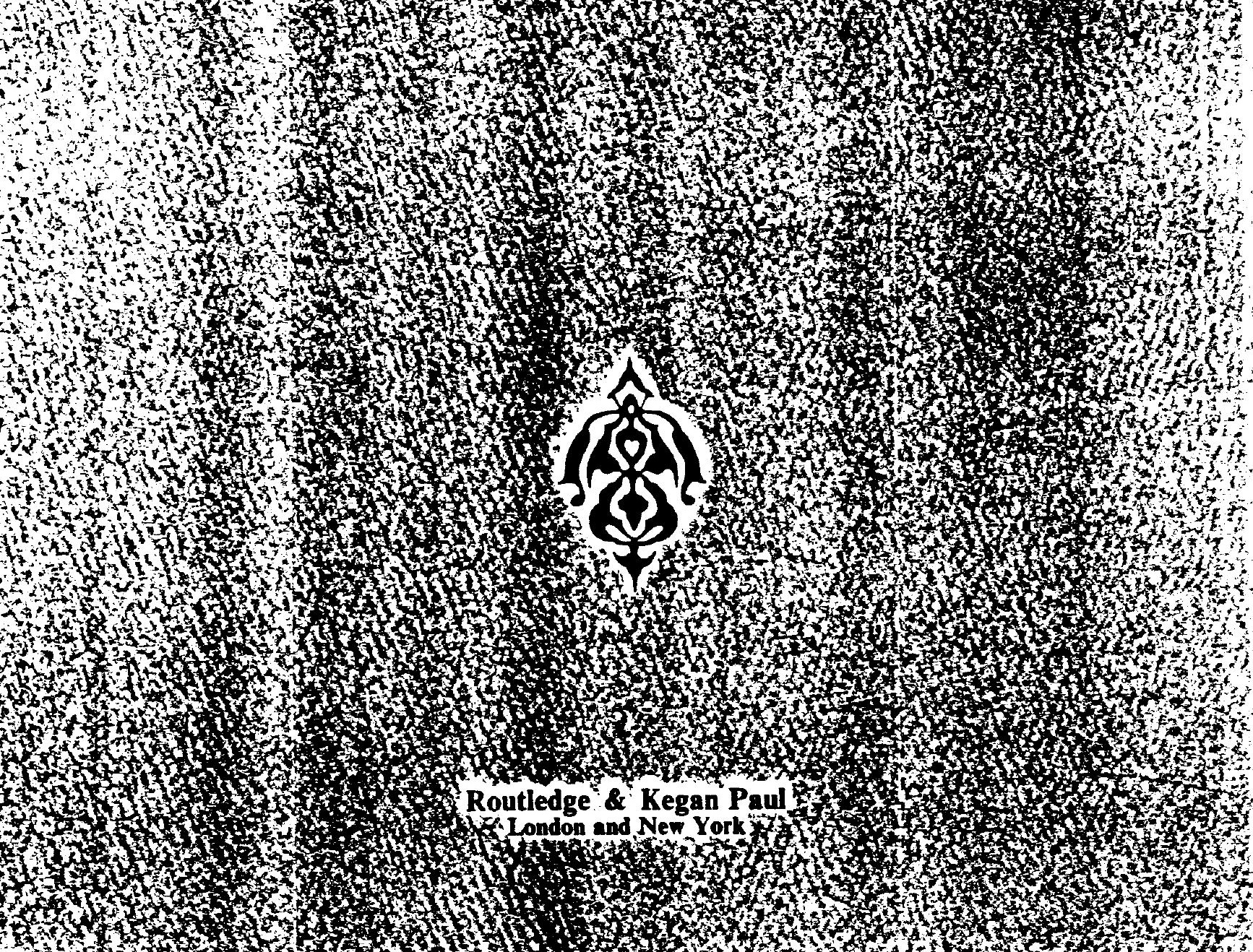

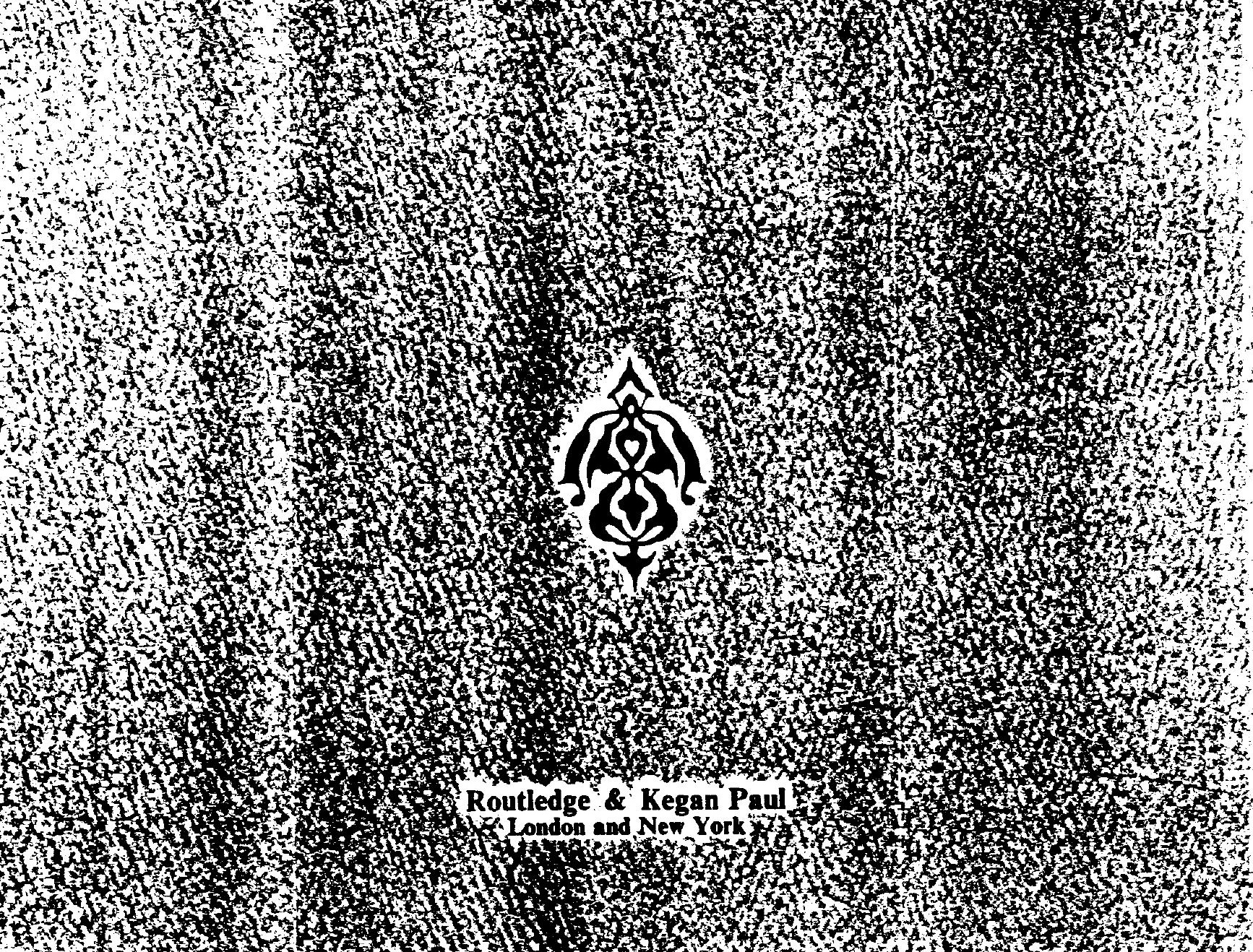

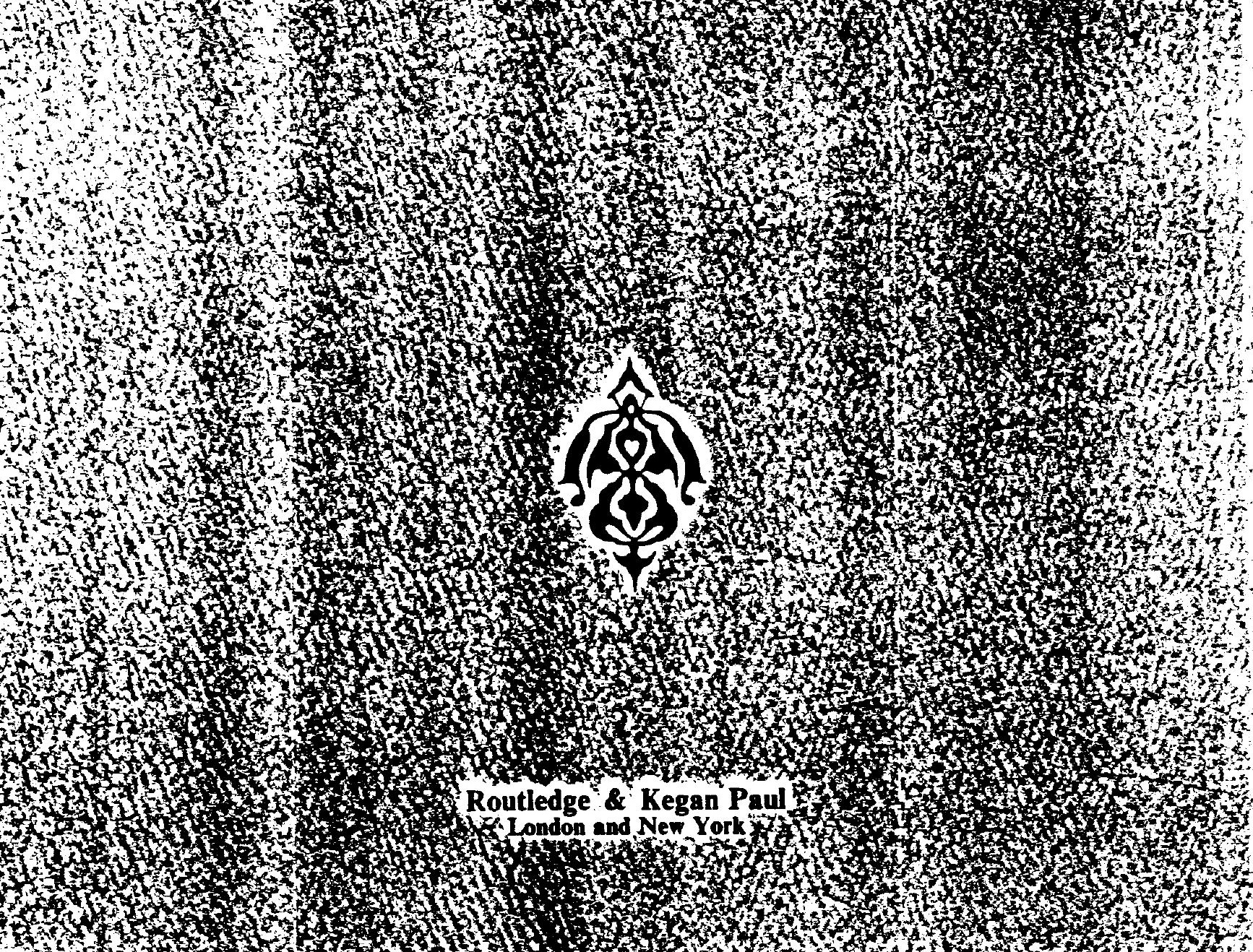

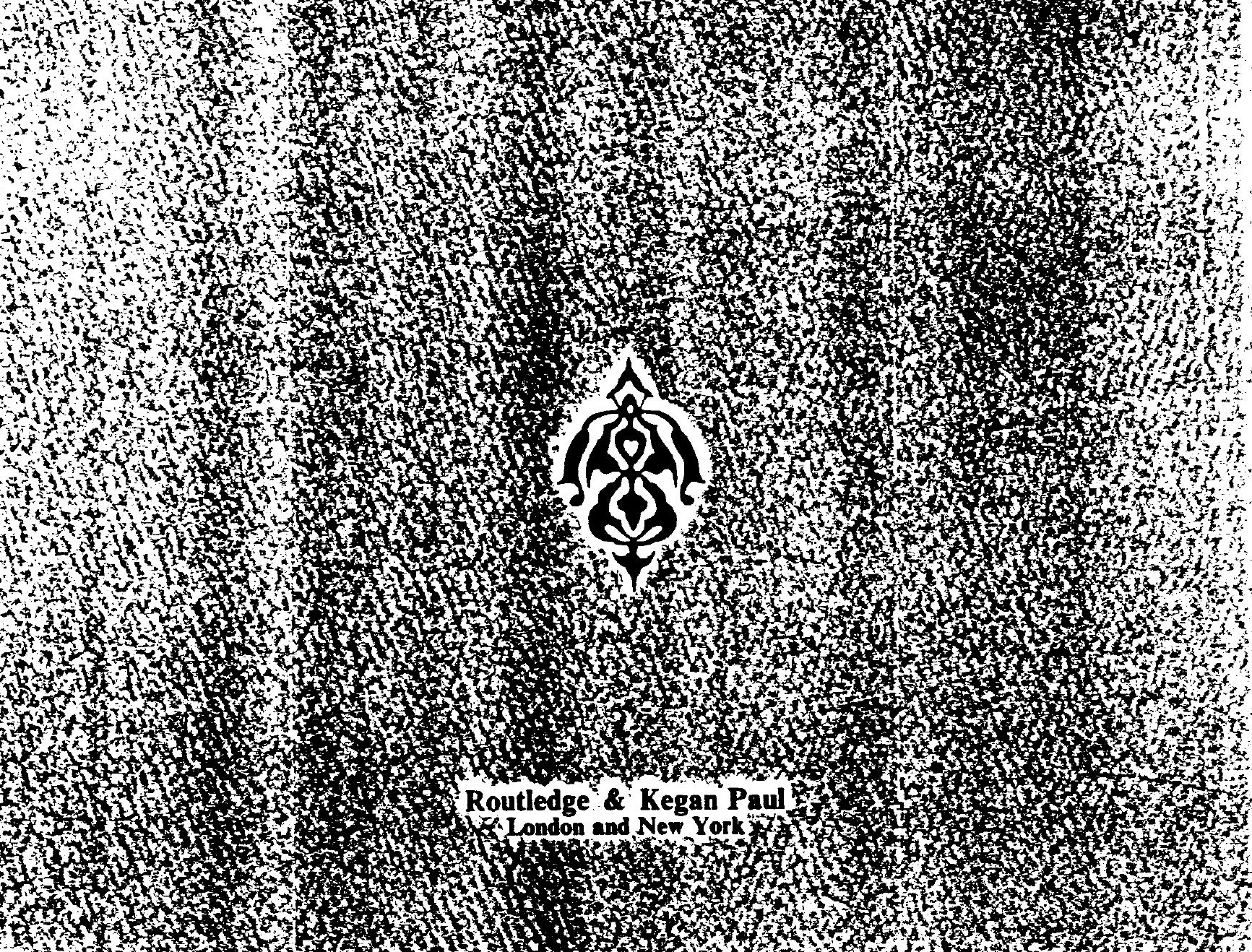



Fascicle 4, 1988:

cool pavilions where the inhabitants may drink a wine that does not intoxicate. A gașida by Mo'ezzi praising a royal garden and probably dedicated to the Saljuq Maleksāh, contains many of the features of the garden of Paradise: the king like the sun and his throne raised to the seventh heaven, the presence of Rezwain, fruit trees, streams of water, and houris (Divān, ed. 'A. Eqbāl, Tehran, 1318 S./1939-40, p. 315). The idea of an earthly Paradise captured the imagination of Persian poets, and the image was so powerful that it appears as late as the nineteenth century in a gasida of the Qajar poet Falh'Ali Khan Şabã, and the great nineteenth-century garden in Shiraz was called Bāö-e Eram (q.v.), afler the earthly rival of Paradise.

From the image of the garden as an earthly Paradise, mystical poets and prose writers extended it to symbol. ize Paradise itself. Again the Koranic passages provided the model, and features of the actual garden such as the watercourses and cypress trees corresponded to the divine archetype. The cypress tree, for example, is likened to the Țüba, and then, in a line from Hăfez, associated with his beloved: "You think about the Tuba tree and I about my beloved's stature; everyone thinks according to his aspiration" (Divān, ed. M. M. Qazvin and Q. Gani, Tehran, 1330 S./1951.52, p. 40). The beloved was frequently described as one of the houris who were promised to the faithful for their enjoyment. In this regard, the 7th/13th-century mystic Rüzbehăn Baqli "draws our attention to the alleged prophetic tradition that one should find spiritual recreation by looking at three things: water, greenery, and a lovely face" (A. Schimmel, 1976, p. 23). For Jalâl-al-Dìn Rúmi, the garden becomes a symbol of divine beauty which both displays and conceals the elernal beauly of the archetypal gardener, God. The mystical lover and his divine beloved are like a rose and its thorn. When the lover becomes one with the beloved, the rose becomes one with the thorn and all duality is resolved.

In modern poetry, the garden continues to be prominent image, byt now it often appears in contexts of social criticism as well as of love. In 1932 Abu'lQāsem Lāhūti wrole a poem entilled "Bāḡbān" (The gardener) in which he compares Stalin to wise gardener who knows best what 10 prune in the garden and what to encourage. More recently, Forūg Farrokzzād in "Del-am barâ-ye bāḡča misũzad" (My heart bleeds for the garden) used a withered and dying garden at the back of her house as a symbol of Iranian culture and society in her lime. She remembers the garden as flourishing when she was a child, and now that she is an adult she finds that people are filled with self-concern but nobody cares for the garden. In a different vein, in her poem "Fath-e bãä" (The victory of the garden) is a joyful love poem set in a garden, using garden imagery to express her feelings.

The garden is not always an image of happiness and beauly, however. In classical poetry, sutumn in the garden was a time of sadness and nostalgia, when cold winds take the place of warm breezes and black and white are the predominant colors (crows and snow). A modern poet has used the garden as the central image in a poem consoling a friend on the death of his child: "Kadiv my friend, Iruly death's hand is fickle. It always plucks the rose and never sees the thorns and twigs. Instead of the brush and thorns, it carries the rose from the garden: what a sinister gardener, what a fearful

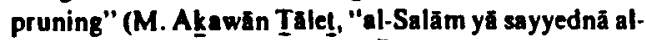
Kadiv," Negin 9, no. 99, 1352 \$./1973-74, p. 10).

As conceplualized in literature, the garden comes to symbolize man's relation to nature in Persian culture. The garden's life cycle parallels that of man: Each has its youth and spring and its autumn and decline. However, the stylized, idealized idea of the garden presented in poetry represents a stark contrast with what lies outside the garden wall: the desert. Hot, dry, dangerous, and inhospitable, the desert is always a threat to life, and the wall serves to keep the desert out as it keeps the garden in. Within the wall, nature is controlted and made to serve the purposes of man: The chaos and danger of nature outside are changed to order and security. In this small Paradise man, not nature, is dominant, and nature can be enjoyed on man's terms.

Bibliography: C. H. de Fouchécour, La descriplion de la nature dans la poésie lyrique persane du XIe siecle, Paris, 1969. William Hanaway, "Paradise on Earth: The Terrestrial Garden in Pers an Literature," in The Islamic Garden, ed. R. Ettinghausen, Washing. ton, D. C., 1976, pp. 43.67. Annemarie Schimmel, "The Celestial Garden in Islam," ibid., pp. 11.39. D. N. Wilber, Persian Gardens and Garden Pavilions, Rutland, Vermont, 1962.

(W.L. Hanaway)

\section{iv. In Afghanistan}

Much of Afghanistan consists of treeless craggy mounta ins, dry sandy deserts, or semi-desert plains. The people inhabiting this land have consequen lly cherished all forms of gardens, which have become an integral part of Afghàn culture. Villagers hold meetings and socialize in their orchards, middle-class urbanites delight in visiting outlying gardens, and the wealthy most often have large gardens inside their walled compounds. Some maintain gardens outside the cities, with or without structures, to which they repair on weekends and holidays.

Pre-Mughal gardens. Since the time the Achaemenids began their eastward expansion in the sixth century B.C., the Alghan area has periodically come under the rule of empires originating in Iran, Central Asia, and India, all of which nurtured garden traditions. Because these earliest gardens were destroyed by the passage of conquering armies one must turn to descriptions by ancient writers or the findings of archeologists in order to glean any information about them. For instance, in 1151 A.D. 'All'-al-Din Guri destroyed the gardenpalaces of the Ghaznavids (977/1 186) in Gazni (see the summary report on the ltalian Archeological Mission in Arghanistan by $\mathrm{A}$. Bombaci and U. Scerrato in Eası and West, N. S. 10, 1959, pp. 3-56) as well as those at Bost

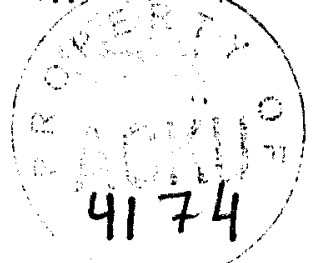


and Laškari Bāzār (D. Schlumberger, "Lashkari Bazar," in MDAFA 18, 1963, p. 80). The armies of Jengiz Khan (1220) and Tĩmũr (Tamerlane; 1281) wrought much havoc (Klaus Fischer, Nimruz, Bonn, 1, 1976; 11, 1974), but their Timurid and Mughal successors, ruling at Herat and Kabul, initiated a cultural renaissance which touched the entire Indo-Jranian region. Gardens were celebrated components of this florescence.

In Herat, the gardens at Gāzargāh tended by Tĩmūr's son, Sāhrok (d. 1447) and those at Takkt-e Safar created by the grandson of Timür's son 'Omar, Sultan Hosayn Bāyqarā (d. 1506), have lost all semblance to their original Persian garden forms but their names remain, recalling a golden age.

Mughal gardens. Kabul was taken in 1504 by a young fugitive from Farḡāna, a descendant of both Jengiz Khan and Timür who was destined to become the emperor Bābor (r. 1526-30), founder of the Mughal empire of India (1526-1857). The adornment of Kabul and its environs became his lifelong passion. In his memoirs, the Bābor-nāma (tr. A. Beveridge, London, 1917), Babur writes that scarcely a year after his lakeover he purchased a garden with "great plane (Čnär) trees" at Estālef, a hillside village 34 miles north of Kabul. Here he built a takı under the cenär and made the "zig-zag" water channels "straight and orderly" to conform to the ideals of a Persian garden (p. 216). Just below this garden he enclosed the spring of $K a \overline{a j a}$ Seh Yārān (Three friends) in mortared stone-work so as to better admire the argavann (Judas tree or red bud; p. 217). The lakı with its cenär and the spring with its argavaran continued to be popular picnic spols up until the end of the 1970s when war ravaged the area.

Bābor mentions over twelve gardens outside the walled city of Kabul where he met envoys and distributed robes of honor (Čenār-bāàg, p. 40I), cavorted with friends at all-night, all-day wine-drinking parties (Bāō-e Banaßsa [Violet garden]; pp. 395, 414), or recuperated (C̄àr-bāḡ; p. 254). In India he remembered the gardens fondly and continued to send letters concerning their upkeep until the lime of his death (p. 645).

Bäbor's will directed that his body be returned to a garden in Kabul, but the original name is unknown. The emperor Jahāngir's (r. 1569-1627) memoirs, the Tüzoke jahāngîri (1r. A. Rogers, London, 1914) lists seven famous Kabul gardens he "perambulated" in 1607 (p. 106), but gives no name to the garden where he visited Bābor's tomb and distributed alms (p. 110). The Pädšäh-näma lists ten gardens in Kabul at the time of Shah Jahān's (r. 1627-58) visit in 1638, and gives details of the orders he gave for embellishing the tomb site, but no name of the garden is specified (appendix $V$ in Baburnama, tr.).

Nevertheless, this account describes the garden as being $\mathbf{5 0 0}$ yards long with 15 terraces $\mathbf{3 0}$ yards apart, and 12 waterfalls cascading into marbled reservoirs on the tenth and ninth terraces, and at the entrance at the bottom of the slope. Shah Jahān ordered the tomb on the fourteenth terrace to be surrounded by a pierced. marble screen and a marble mosque built on the terrace below. It was completed in 1640 (inscription).

This fits the configuration of Bā $\bar{g}-e$ Bäbor today, but only the general form, the terraces, three venerable cenär, the mosque and tomb are recognizable. In 1883 when Amir 'Abd-al-Rahmann gave up residence in the old city of Kabul (Fayz Mohammad, Serāj al-law'ärik. Kabul, 1915, p. 379), he constructed a pavilion with a wooden-pillared verandah over the reservoir on the tenth terrace, and a large haram-sarāy nearby. The gardens then gradually assumed the form of an English garden much favored by later royal families. Ladies' mèlas (fairs) and other festive occasions were held here, including the coronation of Amir Habib-Allāh (r. 1901. 19; K. Seraj and N. H. Dupree, The KES Collection of Vintage Pholographs, New York, 1979, nos. 90-93).

The pavilion and the haram-saray were later used as residences for foreigners (A. Hamilton, Afghanistan, London, 1906, pp. 354, 375) and embassies (O. von Niedermayer, Afghanistan, Leipzig, 1925, pp. 31-32; E Trinkler, Through the Heart of Afghanistan, tr. B. Featherston, London, 1928, p. 176). Finally, Bāḡ-e Bābor became a public park and swimming pools were added, but the complex was increasingly neglected during the 1960s when the pavilion became a hospital and the haram-sarāy a boarding school for tribal boys. The Italian archeological mission (IsMEO) began the restoration of the mosque in 1964 and in 1970 a survey considered the possibility of reconstructing the gardens in the Mughal style (M. Parpagliolo, Kabul: The Bagh-iBabur, Rome, 1972). These plans were never implemented.

The only Mughal garden in Afghanistan retaining any of its original a ppearance is the garden at Nemla, 26 miles west of Jalāābād on the old road to Kabul. Local lore credits Nũr Jahān, wife of Emperor Jahāngir who was renowned for her gardens, with its creation. In his memoirs the emperor speaks of creating the Jahānārā (World-adorning) garden in Kabul in 1607 (p. 106), but makes no mention of a garden at Nemla although he describes a grand hunt in its vicinity on their way back to India (p. 125). Architectural details suggest a date between the end of the sixteenth and the beginning of the seventeenth centuries, however (M. Parpagliolo, p. 2, n. 3).

. The enclosed garden is $\mathbf{4 0 0}$ square yards and contains many classic Mughal elements including an orderly grid pattern of intersecting water channels lined with cypress interspersed with poplar and fruit trees. One waterfall wall is honeycombed with deep niches in which candles were placed behind the cascade, a favorite detail of the period. The bungalow now at its center was built by Amir Habib-Allāh (r. 1901-19).

Post-Mughal gardens. The next period of extensive garden building began at the end of the nineteenth century under Amir 'Abd-al-Rahmān (r. 1880-1901) whose palaces were set in walled parklike gardens a bout which he writes movingly in his autobiography (The Life of Abdur Rahman: Amir of Afghanistan, ed. Sultan 
Mahomed Khan, London, 1900, II, p. 104). The amir retained an English gardener from Yorkshire named Wild (J. A. Gray, Al the Court of the Amir, London, 1895, p. 482) to oversee these gardens filled with trellises, arbors, reflecting pools, sculplured rountains, and Iall gas lamps, fealures which became prominent in subsequent periods (K. Seraj, no. 89, dated 1900).

Outside the walled city of Kabul, west of the river, the amir built a massive S00-yard square citadel (Arg; ca. 1882) with "a garden nearly as large as the whole city of Kabul around it" (1 he Life of Abdur Rahman II, p. 61). Spacious courtyard gardens were planted throughout the complex, and the amir's private pavilion, the Kot-e Bāğča (House of the Little Garden), was surrounded with fragrant nowers (Hamilton, p. 350). The Arg continues to be the seat of government, but buildings have encroached on most of the outer garden space. The amir was proud of his building program (ibid., p. 68) and many of his palaces are still in use, although somewhat altered. Bāğ-e Sāhi with its adjoing haramsarāy' in Bāê-e Kawkab (Star garden; begun 1300/1883, completed ( 303/1887, Fayz Moḥammad, pp. 424, 489) in the eastern town of Jalaläbäd, the winter capital, has been in continuous use and the eleven acres of lush gardens at Bā̄̄-e Săhi were meticulously maintained. It has rarely been open to the public. Manzel-bāg (begun 1300/1883, completed 1302/1884; Fayz Mohammad, p. 417) in a 20-acre walled garden one stage (manzel) east of the southern city of Kandahar, has served variously as a holel, a cinema, and a tractor depol so the gardens are largely depleted but still retain vestiges of their former stale. The massive Bāg-e Jahānāră palace at Kolm (begun 1307/1889, completed 1309/1892; Fayz Mohammad, p. 784) in the north was highlighted by slately firs, fruit trees, terraced gardens, and a reflecting pool. Restored in 1975 as a museum, it was rendered uninhabilable by an earthquake in 1976.

In Kabul, the 30-acre garden surrounding the Cehelsotūn (Forty pillars) palace (1880; inscription) are still well-maintained. Outside the south gate of the Arg there were two garden-sarais, Būstăn (Garden) and Golestān (Rose-garden). Named after works by the renowned thirleenth-century poet, Sa'di, often quoted by Bābor, these sarais had once belonged to Oloğ Beg Kaboli, an uncle of Bäbor's who ruled Kabul and Gazni from ca. 1464-1501 (Baburnama, pp. 95, 251). Here Amir 'Abdal-Rahmañ built a palace with adjoining haram-saräy (1893; inscription). The amir's palace in the Būstănsarăy eventually became his mausoleum, and in 1964 the surfounding walls were removed to create Kabul's newest public garden called Zarnegăr (Adorned with gold)

The many-domed and arcuated palace at $B a z-e$ Bala (1893; Gray, p. 498) located on a high, vine-covered hill some 2.5 miles west of Kabul best represents the amir's garden-palaces. It has been accessible to the public since it became a fashionable restaurant after restoration in 1966. The plan, clearly derived from the Central Asian Islamic Iradition, utilizes a square with two spacious high-domed halls at the center and four small-domed rooms at each corner connected by wide colonnaded verandahs.

The exterior is linished in gleaming white gypsum plaster. The whitewashed interior ornamentation, in both impressed and carved plasterwork, is classically lslamic, depicting arabesques and a variety of floral patterns; patera painted in bold colors are set with mirrors. Arched openings belween rooms were hung with embroidered hangings in place of doors, and the rooms were provided with such novelties as wallfireplaces, wall-lighting fixtures, and massive imported crystal chandeliers. A Mughal-style fountain originally in the entrance hall was not included in the restoration, but the reflecting pool occupying a high terrace on the east was relained. The amir presided over darbärs from a window overlooking the pool (The Life of Abdur Rahman 11, Irontispiece) and died in the same room at midnight on 2 October 1901.

'Abd-al-Rahman's son, Amir Habib-Allāh, built lavish palaces largely in British colonial style, but the next garden-building surge occurred under his son, King Amān-Allāh (r. 1919-29). The garden landscaping at the center of Dar al-Amann (1923), a new city six miles south of Kabul, caused some western visiturs to "gasp" (J. Fleming, Asia 29/4, p. 328). A mān-Allāi. advocated tearing down garden walls and opened the first public zarden, Bâg-e 'Omími, al the sile of Babor's Carr-bāg along the Kabul iiver. It gradually gave way to buildings, but the landscaped complex of terraces forming Amăn-Allah's Băg-e 'Omumi in the hill resort of Pağmãn, 12 miles west of Kabul, continued to be popular until the current hostilities erupled in 1979. II was furnished with fountains, a café, a band stand, a cinema/theater, and an amphitheater forming the core of an ambitious building program carefully regulaled by the Nezärn-näma-ye ta'mīrät-e Pağmān (July, 1922). Article 4 of this building code required all structures to be fronted with "gardens of willows, cenärs, and other nowering shrubs" so that the entire town might resemble a zarden. The last Arghan monarch, Mo. hammad Zafiir Shah (r. 1922-73) was an avid horticulturist and continually embellished the more formal pnblic gardens at the Tapa (King's garden), also in Pağmăn.

Bibliagraphy: See also S. Crowe et al., The Gardens of Mughul India, London, 1972. N. H. Dupree, "Early Twentieth Century Arghan Adaptations of Eutopean Architecture," Art and Archaeology Research Papers 11, London, 1977, pp. 15-21. Idem, "A Building Boom in the Hindukush," Lotus International 26, Milan, 1980, pp. 114-21. Gul-badan Begum, Humayun-nama, tr. H. Beveridge, London, 1902. F. Martin, Under the Absolute Amir, London, 1907. C. Masson, Narratives of Various Journeys in Balochistan, Afghanistan, the Punjab and Kalat, London, 1844 (on Bág-e Băbor, see 11, p. 239). E. and A. Thornton, Leaves from an Afghan Scrapbook, London, 1910. D. N. Wilber, Persian Gardens and Garden Pavilians, Tokyo, 1962.

(N. H. DUPREE) 